\title{
RECENT FLUCTUATIONS OF RAKHIOT GLACIER, NANGA PARBAT, PUNJAB HIMALAYA, PAKISTAN
}

\author{
By JAMES S. GARDNER
}

(Department of Geography, University of Waterloo, Waterloo, Ontario N2L 3G1, Canada)

ABSTRACT. A 1985 survey at Rakhiot Glacier, Nanga Parbat, Punjab Himalaya, indicates that the glacier terminus is advanced about $200 \mathrm{~m}$ from its 1954 position. Between 1930 and 1954, the dates of previous surveys, the glacier terminus had thinned and back-wasted $450 \mathrm{~m}$. The recession prior to the 1960s, followed by advance into the 1970 s and perhaps 1980s, parallels patterns of glacier fluctuation found in the adjacent western and central Karakorum.

RÉSUMÉ. Fluctuations récentes du Rakhiot Glacier, Nanga Parbat, Punjab Himalaya, Pakistan. Les mesures de 1985 sur le Rakhiot Glacier, Nanga Parbat, Punjab Himalaya, montrent que le front du glacier s'est avancé d'environ $200 \mathrm{~m}$ par rapport à sa position de 1954. Entre 1930 et 1954, dates des mesures antérieures, la langue terminale s'était amincie et retirée sur $450 \mathrm{~m}$. Le recul

\section{INTRODUCTION}

Rakhiot Glacier, on the north slope of Nanga Parbat, was subject to surveys of terminus position and surface velocity in 1934 and 1954. As such, it is one of the best documented of western Himalayan glaciers and the resultant data were used by Mayewski and Jeschke (1979) in their inventory of Himalayan and trans-Himalayan glacier fluctuations. In that inventory, recession rates of $30 \mathrm{~m}$ year $^{-1}$ in the 1930-60 period for Rakhiot and Chungphar Glaciers on the south side of the Nanga Parbat massif appeared high relative to other Nanga Parbat glaciers and Himalayan glaciers generally.

The purpose of this note is to provide data on the Rakhiot Glacier terminus position in 1985, thereby completing a half century of record. Rakhiot Glacier was visited in July 1985, as part of the field programme of the Snow and Ice Hydrology Project in the Upper Indus Basin, Pakistan. This is a collaborative research project supported jointly by the International Development Research Centre in Canada, the Water and Power Development Authority in Pakistan, and Wilfrid Laurier University in Waterloo, Canada.

The Nanga Parbat massif is a significant topographic feature in the Upper Indus Basin and one of the most heavily glacierized areas in the western Himalaya (Fig. 1). Kick (1980) described 69 glaciers on Nanga Parbat, covering $302 \mathrm{~km}^{2}$ and having an estimated volume of $25 \mathrm{~km}^{3}$. Rakhiot Glacier, $14 \mathrm{~km}$ long and covering about $32 \mathrm{~km}^{2}$ of connected glacier area, is one of the largest of these glaciers. It is a steep glacier, typical of Nanga Parbat, dropping $4621 \mathrm{~m}$ over $14 \mathrm{~km}$. Within this profile are: the Rakhiot Glacier firn, a low-gradient basin above $5200 \mathrm{~m}$, covering $13 \mathrm{~km}^{2}$, and comprising most of the accumulation area; the ice fall which descends $1500 \mathrm{~m}$ over $2 \mathrm{~km}$; and lower Rakhiot Glacier extending $8 \mathrm{~km}$ with an elevation change of $700 \mathrm{~m}$ and comprising most of the ablation area.

The glaciers of the Nanga Parbat massif have received considerable scientific attention over a period dating from 1856 (Kick, 1975). Detailed surveys of surface velocities and ice margins of several glaciers, including Rakhiot Glacier, were made during the 1934 German Expedition to Nanga antérieur aux années 1960, suivi d'une avance dans les années 1970 et peut être 1980, montre une évolution parallèle aux fluctuations recontrées dans l'ouest et au centre du Karakorum proche.

ZUSAMMENFAsSUng. Jüngere Schwankungen des Rakhiot Glacier am Nanga Parbat, Punjab Himalaya, Pakistan. Eine Vermessung des Rakhiot Glacier am Nanga Parbat im Jahre 1985 zeigt, dass die Gletscherzunge seit 1954 etwa $200 \mathrm{~m}$ vorgerückt ist. Zwischen 1930 und 1954, den Zeitpunkten früherer Vermessungen, war die Gletscherzunge ausgedünnt und $450 \mathrm{~m}$ zurückgegangen. Der Rückzug vor den $60 \mathrm{er}-J a h r e n$, gefolgt von einem Vorstoss in den 70er- und vermutlich $80 \mathrm{er}-J a h r e n$, stimmt mit Schwankungsbeobachtungen im benachbarten westlichen und mittleren Karakorum überein.

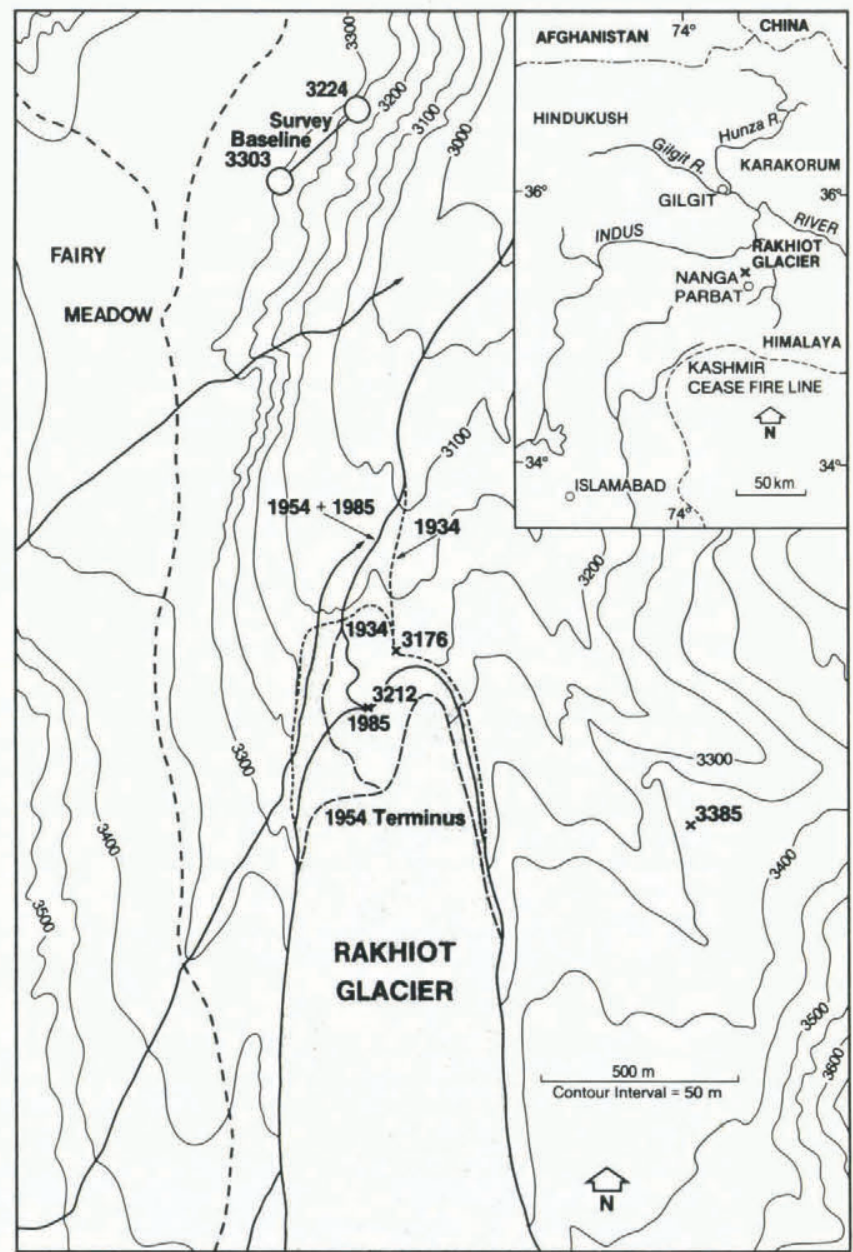

Fig. 1. The location of Rakhiot Glacier and its variable terminus positions, 1934-85. 
Parbat (Finsterwalder, 1935, 1937) (Fig. 1). Pillewizer (1956) found that by 1954 the Rakhiot Glacier terminus had backwasted $450 \mathrm{~m}$ and that surface down-wasting extended $1.5 \mathrm{~km}$ up-glacier. By 1954 a significant shift in pro-glacial drainage from the right bank to the center left bank had also occurred. Based on high surface velocities in the ice-fall area in 1954, Pillewizer speculated that Rakhiot Glacier would advance in the near future (personal communication from W. Kick, 1986). Photographs taken at Rakhiot Glacier in October 1959 by the botanist, Dr G. Repp, indicate the terminus was in approximately the same position as in 1954.

\section{THE 1985 SURVEY}

The 1985 field work included a transit survey of the terminus position (previous surveys used photo-theodolites) using the 1934 and 1954 base line. The terminus area in July 1985 is shown in Figure 2. The photograph was taken from Station IB $(3303 \mathrm{~m})$ indicated on the Finsterwalder 1: 50000 topographic map and used as the west end of the terminus survey base line in 1934, 1954, and 1985. Figure 1, depicting terminus fluctuations, was constructed using previous publications, 1985 survey data, and photographs taken at the three survey dates. In 1934, the farthest extent of ice was at $3155 \mathrm{~m}$ and the stream portal was at $3176 \mathrm{~m}$ elevation (Finsterwalder, 1935, 1937), $100 \mathrm{~m}$ horizontal distance up-glacier and towards the right-center of the glacier. In 1954, the terminus had retreated approximately $450 \mathrm{~m}$ with the farthest extent of ice being a shallow debris-covered tongue on the glacier right bank. The stream portal had shifted to the center of the glacier (Fig. 1). The terminus survey in 1985 placed the portal elevation at $3212 \mathrm{~m}, 140 \mathrm{~m}$ up-glacier from the 1934 portal location and approximately $250 \mathrm{~m}$ up-glacier from the farthest extent of ice in 1934. This represents a $200 \mathrm{~m}$ advance of the terminus, as defined by the portal, since 1954. The farthest extent of ice in 1985 was represented by a debris-covered lobe on the glacier right bank. On the distal margin of this lobe was some thrust ridging, suggestive of advance. In 1985, the stream portal was still located in the glacier center but the pro-glacial stream had shifted to the left bank. Comparison of photographs taken in 1954 and 1985 also indicates that the terminus area has thickened. Thus, maximum down-wasting at the terminus since 1934 has been approximately $9 \mathrm{~m}$. Photographs indicate that the terminus morphology characterized by hummocky debris-covered ice, of ten indicative of stagnation, is virtually unchanged in appearance.

\section{CONCLUSION}

In 1985, Rakhiot Glacier exhibited many of the same morphological characteristics as it did in 1934 and 1954. The terminus area and lower ablation zone remain debris-covered in patterns similar to 1934 and 1954. Surface

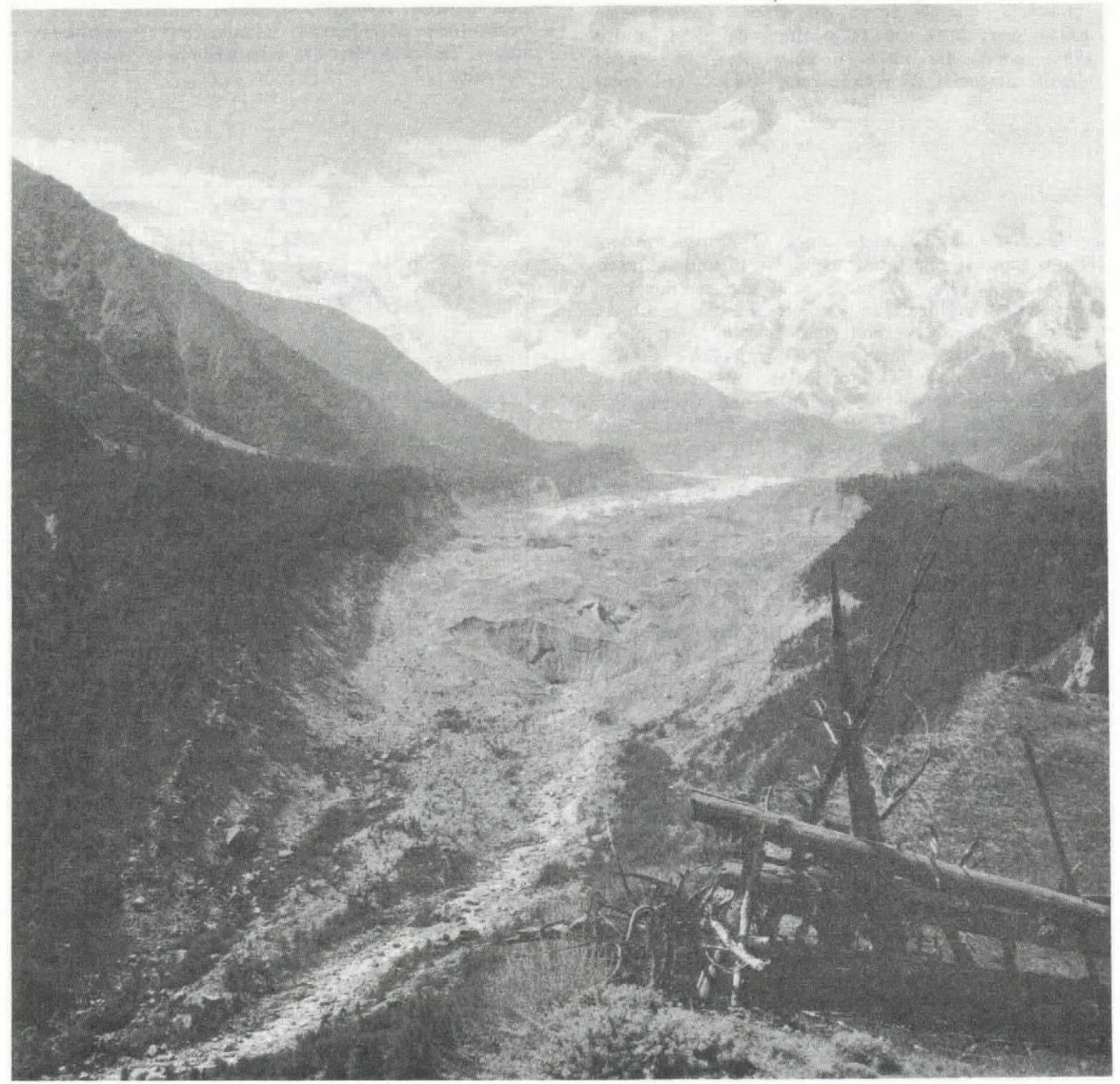

Fig. 2. The terminus and lower ablation zone of Rakhiot Glacier, July 1985. The photograph was taken from Fairy Meadow Station IB (bench mark $3303 \mathrm{~m}$ ). 
down-wasting since 1934 extended only $1.5-2.0 \mathrm{~km}$ up-glacier. Terminus recession since 1934 amounted to $250 \mathrm{~m}(4.9 \mathrm{~m} /$ year $)$. However, within this recession are two phases: rapid recession of $450 \mathrm{~m}$ ( $30 \mathrm{~m} /$ year) from 1934 to 1954 , and advance of about $200 \mathrm{~m}$ sometime between 1954 and 1985 .

These data from Rakhiot Glacier are consistent with recent results from studies of adjacent Karakorum Glaciers. The period 1930-60 was characterized by generalized recession and terminus down-wasting (Mayewski and Jeschke, 1979; Zhang Xiang-song and others, 1981). In the 1970 s and 1980s, the picture was more heterogeneous with reduced rates of recession and oscillations about a roughly stationary terminus noted at such glaciers as Batura and Pasu Glaciers, and advances noted on Hasanabad, Minapin, Ghulkin, and Biafo Glaciers, in addition to Rakhiot Glacier (Goudie and others, 1984; Snow and Ice Hydrology Project, 1986). The fact that Rakhiot Glacier has undergone recent fluctuations similar to those of glaciers in other parts of the Upper Indus Basin adds further credence to the proposal that glaciers in the region show a similar though variable rate of response to generalized environmental changes (Mayewski and others, 1980; Goudie and others, 1984).

\section{ACKNOWLEDGEMENTS}

The financial support of the International Development Research Centre (Canada) and the Water and Power Development Authority (Pakistan) through the Snow and Ice Hydrology Project - Upper Indus Basin (Wilfrid Laurier University, Waterloo, Canada) is acknowledged. The field assistance of F. de Scally (University of Waterloo), H. Afzal (WAPDA), M. Anwar (WAPDA), and F. Rahmat (Tato Village) is appreciated. Photographs and comments by $W$ Pillewizer, G. Repp, and W. Kick are gratefully acknowledged.

\section{REFERENCES}

Finsterwalder, R. 1935. The scientific work of the German Himalayan Expedition to Nanga Parbat, 1934. Himalayan Journal, Vol. 7, p. 44-52.
Finsterwalder, R. 1937. Die Gletscher der Nanga Parbat. Zeitschrift für Gletscherkunde für Eiszeitforschung und Geschichte des Klimas, Bd. 25, p. 57-108.

Goudie, A.S., and others. 1984. Recent fluctuations in some glaciers of the western Karakoram mountains, Hunza, Pakistan, by A.S. Goudie, D.K.C. Jones, and D. Brunsden. (In Miller, K.J., ed. The International Karakoram Project. Cambridge, etc., Cambridge University Press, Vol. 2, p. 411-55.)

Kick, W. 1975. Application of geodesy, photogrammetry, history and geography to the study of long-term mass balances of central Asiatic glaciers. [Union Géodésique et Géophysique Internationale. Association Internationale des Sciences Hydrologiques. Commission des Neiges et Glaces.] Symposium. Neiges et glaces. Actes du colloque de Moscow, août 1971, p. 150-60. (IAHS-AISH Publication No. 104.)

Kick, W. 1980. Material for the glacier inventory of the Indus drainage basin - the Nanga Parbat massif. [Union Géodésique et Géophysique Internationale. Association Internationale des Sciences Hydrologiques. Commission des Neiges et Glaces.] Atelier Inventaire Mondial des Glaciers. Actes de l'atelier de Riederalp, Suisse, 17-22 septembre 1978, organisé par le Secrétariat Technique Temporaire pour l'Inventaire Mondial des Glaciers, p. 105-09. (IAHS-AISH Publication No. 126.)

Mayewski, P.A., and Jeschke, P.A. 1979. Himalayan and Trans-Himalayan glacier fluctuations since A.D. 1812 . Arctic and Alpine Research, Vol. 11, No. 3, p. 267-87.

Mayewski, P.A., and others. 1980. Himalayan and Trans-Himalayan glacier fluctuations and the south Asian monsoon record, by P.A. Mayewski, G.P. Pregent, P.A. Jeschke, and N. Ahmad. Arctic and Alpine Research, Vol. 12, No. 2, p. 171-82.

Pillewizer, W. 1956. Der Rakhiot-Gletscher am Nanga Parbat im Jahre 1954. Zeitschrift für Gletscherkunde und Glazialgeologie, Bd. 3, Ht. 2, p. 181-94.

Snow and Ice Hydrology Project. 1986. Annual report 1985. Waterloo, Ontario, Wilfrid Laurier University.

Zhang Xiang-song, and others. 1981. Recent variations of the existing glaciers on the Qinghai-Xizang plateau, by Zhang Xiang-song, Zheng Ben-xing, and $\mathrm{Xie} \mathrm{Zi}$-chu. (In Geological and ecological studies of the Qinghai-Xizang plateaus. New York, Gordon and Beach Science Publishers, Inc., Vol. 2, p. 1625-29.) 